\title{
PSIKOLOGI PENDIDIKAN BAGI GURU DAN PESERTA DIDIK
}

\author{
Titis Muthiana Taqwim \\ Email: 2010128220023@mhs.ulm.ac.id \\ Program Studi Pendidikan IPS Fakultas Keguruan dan Ilmu Pendidikan \\ Universitas Lambung Mangkurat \\ Banjarmasin
}

\begin{abstract}
Abstrak
Psikologi pendidikan adalah studi ilmiah untuk menekuni, menduga, dan menuntun moral siswa bagi usaha pencapaian tujuan pendidikan dan pencerahan.Aspek psikologi sangat penting untuk peserta didik karena,psikologi dapat membantu seorang guru dalam menentukan teknik pembelajaran yang tepat untuk peserta didiknya. Seorang guru diharapkan memiliki keterampilan dan stategi untuk memehami karakteristik peserta didik nya.Dengan adnya psikologi pendidikan, seorang pendidik akan memahami perbedaan setiap peserta didik dalam kegiatan pembelajaran dan bagaimana seorang pendidik menghadapai perbedaan kepribadian.
\end{abstract}

Kata Kunci: Psikologi, Pendidikan, Peserta Didik, Guru.

\section{PENDAHULUAN}

Psikologi pendidikan ialah ilmu yang sangat penting yang harus dikuasai oleh seorang guru sebagai pendidik dan pengajar.Psikologi pendidikan yaitu mata pelajaran yang penting yang buat seorang pendidik yang bertujuan membantunya memahami perilaku belajar siswa,untuk mambantu menemukan solusi dari masalah yang dihadapi oleh peserta didik serta memberi saran kepada peserta didik. Psikologi sebagai salah satu disiplin ilmu yang sangat digunakan pendidikan.Pemahaman guru terhadap psikologi pendidikan memiliki kontribusi yang sangat bearti dalam kegiatan pembelajaran peserta didik sesui dengan minat,motivasi,perilaku,aspirasi,serta solusi.Sehingga proses kegiatan pengajaran di dalam maupun diluar kelas berlangsung secara nyaman dan menyenangkan. 


\section{Metode Penelitian}

Dalam penulisan artikel ini saya menggunkan metode studi kajian literatur.Penulis menggunkankan jurnal-jurnal dan buku yang relevan.Kemudian, Bahan yang sudah dikumpulkan dan di pilih. Setelah itu ,dibuatlah beberapa serangkaian penulisan secara fakta dan membentuk menjadi sebuah penulisan artikel.

\section{Psikologi Pendidikan}

Jika lihat Psikologi asal mula dari kata "psyche" yang artiya jiwa dan "logos" yang artinya ilmu. Jadi, secara harfiah "psikologi memiliki artinya ilmu tentang jiwa atau ilmu jiwa”. Psikologi termasuk kajian ilmiah yang menbahas mengenai tingkah laku dan proses mental.Maknanya bahwa psikologi pendidikan mempelajari aktivitas atau perilaku peserta didik dan proses mental yang dialami peserta didik yang terjadi selama menjalani pendidikan.Menurut Arthur S Reber, beliau mengatakan bahwa Definisi Psikologi pendidikan adalah sebuah sub-disiplin ilmu psikologi yang berkaitan dengan teori dan masalah kependidikan (Syah, 1997).

Konsep yang menjadi dasar psikologi pendidikan merupakan bahasan sub-disiplin ilmu psikologi yang mempelajari tentang permasalahan psikologis dalam pendidikan, kemudian masalah tadi dapat diselesaikan dalam bentuk konsep, teori dan metode. Psikologi pendidikan dapat digunakan sebgai alat oleh seorang pendidik untuk mengendalikan dirinya serta dapat memberikan usaha belajar kepada kegiatan belajar siswa untuk mencapai tujuan pendidikan.Sehingga dengan adanya ilmu psikologi pendidikan, maka akan membantu kegiatan proses belajar dan mengajar serta sekaligus dapat memahami kondisi dan bagaimana cara mendidik peserta didik sesuai dengan tahap perkembangannya.

\section{Ruang Lingkup Psikologi Pendidikan}

Dalam pendidikan terangkum semua aspek-aspek kehidupan yang membentuk kehidupan manusia, aspek biologis yang berkaitan dengan aktivitas otak dan system saraf, aspek fisik yang berkaitan dengan perkembangan fisik, aspek kognitif yang melihat dan memahami tindakan manusia dalam kerangka pengertian stimulus angsangan dan aspek kejiwaan yang menjadi perpaduan antara kognitif, kesadaran, persepsi serta 
gagasan. Psikologi pendidikan tidak hanya dianggap sebagai suatu psikologi yang dipraktekkan saja. Psikologi pendidikan yaitu sebagai suatu pengetahuan yang mempunyai hak hidup sendiri, karena aspek tertentu dari psikologi pendidikan nyata yang bersifat kefilsafatan tetapi sebagai suatu ilmu pengetahuan psikologi pendidikan telah memiliki susunan dan prinsip atau kebenaran dasar sendiri, fakta yang bersifat obyektif dan teknik yang berguna untuk penelitian. ruang lingkup psikologi pendidikan yaitu sebagai berikut :

a. Pertumbuhan dan Perkembangan Individu

Sejak manusia lahir maka kehidupan mulai ada dan akan mengalami pertumbuhan dan perkembangannya. Di dalam proses pertumbuhan terjadi pula proses perkembangan. Hal ini tidak dapat dipisahkan karena pertumbuhan dan perkembangan adalah suatu hal penting yang mengenai perubahan seorang individu. Oleh karena, itu pertumbuhan dan perkembangan pada umumnya terjadi dalam diri individu akan terus berlanjut tanpa henti hingga di akhir hayat.

b. Kejiwaan Anak

Ruang lingkup kedua yang dikaji oleh psikologi pendidikan adalah psikologi atau keadaan jiwa dari anak. pada masa kanak-kanak adalah masa yang paling mendasar apa yang dialami oleh seseorang akan sangat memberikan makna yang sangat mendalam dan begitu mempengaruhi pembentukan kepribadian seseorang dalam kehidupannya nanti di masyarakat.

\section{c. Motivasi}

Setiap perbuatan yang dilakukan, termasuk perbuatan belajar disebabkan oleh sesuatu dorongan. Dorongan tersebut berasal dari dalam diri seseorang individu untuk mencapai suatu tujuan, dorongan itu lah yang disebut dengan motivasi. Motivasi orang tergantung pada kekuatan motifnya yang ingin dia capai.Disini,motif yang dimaksud ialah ini adalah Menurut tokoh Hersey,Blanchard dan Johnson yaitu "kebutuhan, keinginan, dorongan atau gerak hati dalam diri individu".Dengan kata lain sesuatu yang menggerakkan seseorang untuk melakukan tindakan dengan cara tertentu, atau sekurang-kurangnya mengembangkan hal tertentu (Hodgetts,1996). 


\section{Pentingnya Guru Mendalami Psikologi Pendidikan}

Pendidikan pada hakikat adalah proses pematangan dan pendewaan diri. Melibatkan proses tersebut diharapkan manusia dapat memahami apa artinya dan hakikat hidup, serta untuk bagaimana menjalankan tugas hidup dan kehidupan secara benar.Bidang pendidikan memerlukan pengetahuan tentang psikologi, karena bidang pendidikan dihadapkan pada karakteristik perilaku, kepribadian, sikap, minat, motivasi, perhatian, persepsi, kemampuan berpikir, kecerdasan, fantasi, dan aspek psikologis lainnya. Agar proses pembelajaran berhasil, setiap guru di kelas yang berperan sebagai pendidik dan pengajar harus memahami perbedaan karakteristik psikologis siswa.Sering kali terjadi didalam kelas terjadi gejala gangguan atensi yang menjadi faktor psikologis yang dialami siswa di kelas, hal tersebut harus dikenali dan dipahami oleh guru sebagai pengajar dan pendidik di kelas untuk mencegah dan mengatasi kesulitan belajar yang dihadapi siswa dalam proses mengikuti pembelajaran di kelas. Guru di kelas harus dapat memberikan upaya pencegahan dan penanggulangan masalah yang dihadapi siswa di kelas Guru hendaknya menggunakan metode dan strategi pembelajaran yang dapat menarik perhatian pembelajaran sehingga siswa dapat merasa sangat nyaman dari awal hingga akhir kelas. Dari penjelasan diatas menunjukkan bahwa setiap permasalahan yang dihadapi oleh para guru dalam proses pendidikan. 


\section{SIMPULAN}

Mata kuliah Psikologi Pendidikan bagi seorang calon guru dan guru sebagai dasar pengetahuan yang mendasari profesi mengajar guru. Pendidik yang memiliki pengetahuan tentang Psikologi Pendidikan akan mampu mengembangkan serta menerapkan prinsip psikologi dalam memngamalkannya dan mendidik peserta didik di kelas.Sebagai guru sudah menjadi keharusan untuk bertanggung jawab dalam melaksanakan tugasnya, terlebih bagi semua pendidik. Karena itu, penguasaan terhadap ilmu psikologi pendidikan menjadi suatu tuntutan terhadap orang yang terjun dalam dunia pendidikan sebagai salah satu keahlian seorang pendidik.Sebab,seorang pendidik yang memiliki keahlian mendidik akan mampu membuat peserta didik belajar dan kualitas seorang pendidik memberi pengaruh terhadap peningkatan kompetensi peserta didik. 


\section{REFERENSI}

Abbas, E. W., Wahyu, W., Sofyan, A., \& Sarbaini, S. S., \& Syaharuddin, S.(2016).

Pendidikan Karakter. WAHANA Jaya Abadi.

Arifudin, O., Hidana, R., Julius, A., Doho, D. B., Sormin, E., Ghazali, A., ... \& Bahri, A. S. (2020). Psikologi Pendidikan (Tinjauan Teori Dan Praktis).

Arliman, L. (2021). pendidikan karakter dalam tinjauan psikologi. Ensiklopedia of Journal, $3(3), 181-186$.

Daulay, N. (2019). Psikologi pendidikan dan permasalahan umum peserta didik.

Diananda, A. (2019). Psikologi remaja dan permasalahannya. ISTIGHNA: Jurnal Pendidikan dan Pemikiran Islam, 1(1), 116-133.

Dodi, N. (2016). Pentingnya guru untuk mempelajari psikologi pendidikan. NUSANTARA: Jurnal Ilmu Pengetahuan Sosial, 1(1).

Haryadi, R., \& Cludia, C. (2021). pentingnya psikologi pendidikan bagi guru. Academy of Education Journal, 12(2), 275-284.

Kowal, R. (2015). psikologi pendidikan. RHEMA: Jurnal Teologi Biblika dan Praktika, 1(2).

Pandapotan, S. (2019). Dinamika Pendidikan Karakter dalam Kajian Budaya Dan Psikologi Pendidikan. journal of education, humaniora and social sciences (JEHSS), 2(2), 271-278.

PUTRO, H. P. N. (2020). Jurnal Socius (Pendidikan dan Pembelajaran Ilmu Pengetahuan Sosial).

Rusmaniah, R., Mardiani, F., Handy, M. R. N., Putra, M. A. H., \& Jumriani, J. (2021). Social Services Based on Institutional for Youth Discontinued School. The Innovation of Social Studies Journal, 2(2), 151-158.

Sarbaini, S., ABBAS, E. W., Wahyu, W., \& SOFYAN, A. (2020). pendidikan karakter.

Subiyakto, B., \& Akmal, H. (2020). Profesi Keguruan. 